\title{
DEMOCRACY, RULE OF LAW, AND THE OMBUDSMAN(1)
}

\section{P. Nikiforos DIAMANDOUROS(2)}

As the enlarged European Union gradually adjusts to the newfound realities and dynamics of a re-unification process politically and symbolically signalling the end of the major, traumatic and profound divisions brought about by what I like to think of as the European civil wars of the 20th century, it might be appropriate, indeed opportune, to reflect on the broader political and institutional context directly affecting the capacity of the ombudsman institution to serve citizens and to enhance their ability better to enjoy their rights. Two major parameters profoundly affecting and shaping this context are the rule of law and democracy. The interplay between these two parameters and the institution of the ombudsman shall constitute the object of this short article. ${ }^{1}$

My argument, simply put, will be that the particular temporal sequence in which rule of law and democracy are introduced in a given society and country will directly affect the political and institutional environment within which the ombudsman can operate. More specifically, I wish to argue that where rule of law precedes democracy, the resulting political, institutional and cultural environment will be more hospitable to the fuller actualisation of the ombudsman's potential and more conducive to its serving as a mechanism contributing to the substantive empowerment of citizens. Conversely, the reverse sequence, where the introduction of democracy either precedes that of the rule of law or even coincides with it, constitutes a sub-optimal option from the point of view of citizens' empowerment through the enjoyment of their rights. In what follows I will seek to develop this argument more systematically. ${ }^{2}$

Let me begin by stressing the obvious point that, even though, in contemporary European legal culture, rule of law and democracy are thought of as forming an inseparable and, so to speak, natural pair, they are clearly separable and analytically distinct.

Rule of law describes a condition in which all members of society live under the law, and where no one can operate outside or above the law. Its historical origins derive from European feudalism, and, more specifically, from the tight and complex nexus of reciprocal rights and obligations which, over time, issued from

(1) The article was originally published in: Hans Gammeltoft-Hansen and Jens Olsen, eds., The Danish Ombudsman 2005-Part III, (Copenhagen: Folketingets Ombudsmand, 2005), 11-22.

(2) Avrupa Eski Ombudsmanı 
the contractual relations linking lord and vassal together. Flowing directly from such a situation is the additional principle that, under the rule of law, every person is subject to ordinary law and not to extraordinary or exceptional arrangements. A crucial condition relating to the generation of the rule of law and underpinning its existence is that its general principles are necessarily the product of judicial decisions, in other words, that the courts constitute the foundation upon which the rule of law is built and on which its development and evolution depends. Finally, to confine myself to very basic attributes, rule of law by definition implies the absence of the unrestrained (and therefore potentially arbitrary) exercise of power, so elegantly conveyed by the Latin maxim "Quod principi placuit, legis habet vigorem" [=what pleases the prince has the power of law], which, by assigning paramount value to the ruler's pleasure served for a long time as the intellectual justification and underpinning for absolute government. ${ }^{3}$

A further dimension associated with the rule of law is that, under conditions characterised by its acceptance, the constitution of the state is effected on the basis of what Max Weber described as "legal-rational" rules, which serve as the legal foundation of power and of the state. ${ }^{4}$

Finally, the evolution of the rule of law has, over time, resulted in social and political arrangements, whose distinctive characteristic is that the relationship between rulers and ruled is not direct and immediate, but is rather mediated by structures or institutions enjoying legal recognition and authority, placing effective limits on the power exercised by the ruler. This characteristic of the rule of law and of the pattern of mediated exercise of power that it is associated with was astutely captured and extensively analysed by Montesquieu in his celebrated Spirit of the Laws, under the apt term "corps intermédiaires". ${ }^{5}$

In contrast to the rule of law's more ancient pedigree, democracy is a much more recent phenomenon that is inextricably linked to the political and socioeconomic upheavals that shook the European Continent and the American colonies in the "long century" beginning in the last quarter of the 18th century and lasting well into the 20th. Associated with the gradual expansion of the right of suffrage to an ever increasing number of subjects turned citizens, democracy, and especially its liberal variant, nowadays enjoys undisputed legitimacy not only throughout Europe, which implicitly constitutes the focus of this contribution, but among the overwhelming majority of states around the world. ${ }^{6}$

Definitions of democracy can easily be long and elaborate. For purposes of this analysis, I prefer to adopt a minimalist conceptualisation and to confine myself to identifying some of the basic attributes of democracy that serve as fundamental preconditions for its legitimacy and effectiveness. In my mind, these include (a) the capacity to allow for fair elections, (b) the existence of more than one legal 
parties having the right freely to contest an election, and (c) the absence of what political scientists call "veto groups", capable of effectively interfering with the democratic process and of, in one way or another, subverting or voiding decisions taken by the voters. Traditional examples of such veto groups are the monarchy, the armed forces, or other parts of the state apparatus unwilling to accept the popular verdict of an election as legitimate and final and to abide by it. ${ }^{7}$

An important implication of such a conceptualisation is that democracy cannot be simply equated to parliamentary institutions or to the mere holding of elections. The existence of the former in many parts of the world today and in many parts of Europe in the past did not ensure that the conditions outlined above as basic characteristics of democracy were adequately met. At the same time, even a cursory look around the world will provide ample evidence to support the view that the conditions under which elections are held in many countries do not meet the criteria of fairness, free contestation and absence of veto groups outlined above. Rather than democracies, these can better be thought of as "electoral regimes", whose capacity to meet the formal requisites of democracy is still quite limited. ${ }^{8}$

Let me, finally, make an additional and, in certain ways, more complicated point, which has to do with the relationship between democracy and the legitimacy of the state. To put it simply, acceptance of the legitimacy of the state in the eyes of its citizens constitutes a prior condition for the smooth operation of democracy. In fact, I would take this proposition one step further and argue that if the state is not perceived as legitimate, then the democratic process cannot rectify this problem. This observation serves to clarify an important point of high salience for this analysis. It highlights an essential distinction between rule of law and democracy, by pointing to the fact that the majoritarian logic driving the democratic process cannot, a priori, be used as an instrument for settling issues pertaining to the primacy of the rule of law. To give but one example to which I will return towards the end of my analysis and which has direct relevance to political problems facing a number of more recent European democracies: the democratic process, in other words the majoritarian principle, cannot be made use of to resolve issues relating to the defence of human rights, including the rights of minorities. ${ }^{9}$

In its short modern existence, democracy has assumed many forms and varieties. Depending on which principle or attribute is chosen as a criterion for classification, democracies can be thought of as parliamentary, presidential, or semi-presidential, the latter being used in reference to the type installed in France under the Fifth Republic. Alternatively, we can think of democracies as majoritarian or consensual; or as republics as opposed to constitutional monarchies. 
If we were to move our inquiry to the level of abstract principles informing democracy, I would argue that liberty and equality, two of the most powerful intellectual legacies of the Enlightenment and of the political revolutions this momentous era gave rise to, serve as a solid foundation upon which all modern democracies have been constructed. The relative balance between these two principles built into constitutional formulae and resulting institutional arrangements allows us to distinguish between two variants of modern democracy which have a particular bearing to contemporary political and intellectual debates concerning both democracy and, especially, the quality of democracy in Europe and beyond.

The first variant, which derives its roots from the Jacobin legacy of the French Revolution, privileges equality as the fundamental organisational principle of democracy. Its attractiveness lies in the elegance issuing from its simplicity. According to this conceptualisation of democracy, shorn to its essentials, the sovereign people constitute the sole source of power, whose sole institutional expression is (a mostly unicameral) parliament. In majoritarian systems capable of producing single party cabinets, the party enjoying parliamentary majority constitutes the natural and logical sole expression of popular sovereignty and, as such, can legitimately claim the right to exercise power on behalf of the sovereign people. ${ }^{10}$

The obvious advantages of such an egalitarian conceptualisation of democracy notwithstanding, its major drawback, deriving directly from its preoccupation with equality as its major, if not sole, organisational principle, is that it is driven by what I would describe as a "unidimensional" logic geared to privileging homogeneity over diversity. Pushed to its logical extremes, such an emphasis on homogeneity, so intimately linked to equality, risks generating a flattening dynamic capable of imparting a dimension of "levelling egalitarianism" to the democracy associated with the unidimensional logic underpinning it. In turn, such a conceptualisation of democracy raises serious concerns relating to the observance of the rule of law and the respect for the enjoyment of rights and obligations linked to it. ${ }^{11}$

The alternative variant, which, I hasten to add, seems to be drawing growing attention in recent decades and to serve as is an increasingly attractive paradigm to emulate is characterised by the systematic search for the construction of institutional arrangements capable of embodying various combinations of the principles of equality and liberty. Driving this conceptualisation of democracy is a pluralist logic, whose overriding preoccupation is the search for an optimal balance between institutions alternatively expressive of egalitarian and libertarian principles. Such an overarching balance, which, for its crystallisation, consolidation and entrenchment over time, relies on the generation of a dense network of 
institutional checks and balances or counterweights, akin to Montesquieu's "corps intermediaries", provides better conditions for the observance of the rule of law and for the quality of democracy. ${ }^{12}$

It is, therefore, not accidental that it is in democracies which most approximate this variant that the role of the judiciary as the fountainhead of the rule of law is most developed and respected and acceptance of the ombudsman as a quintessential example of such a counterweight enjoys greatest legitimacy. I simply note that the institution of the ombudsman, initially established in Sweden in 1809 and subsequently spread to Finland in 1919, Denmark in 1955, Norway and New Zealand in 1962, the United Kingdom in 1967 and France in 1972, now exists at the national level in 23 of the 25 Members States in the European Union (and at the regional and local levels in Italy and Germany), as well as in seven out of eight states in Southeastern Europe, and is intimately identified with norms and practices geared to the promotion of the quality of democracy and respect of the rule of law. ${ }^{13}$

Given the foregoing analysis, the questions which almost automatically poses itself is: which combination of rule of law and democracy constitutes a more hospitable environment enabling the ombudsman better to serve as an institutional counterweight capable of defending the rights of citizens, combating maladministration and protecting human rights? For the sake of clarity, I propose to be somewhat schematic and to identify two such combinations or scenarios capable of adequately addressing this question. In the first, which is more typical of more mature democracies, the introduction of the rule of law historically preceded democracy. In all such cases, the prior existence of the rule of law as the fundamental underpinning upon which a state organised along legal-rational rules was erected made it easier to confront the inevitable tensions, turbulence and occasional upheavals associated with the rise in popular participation linked to the introduction of democracy in each country. ${ }^{14}$

In countries where such a sequence resulting in the positive articulation of rule of law and democracy obtained, the emergence of the ombudsman as an institution distinct from, but complementary to, the courts, capable of serving as a non-judicial mechanism of accountability and control geared to the enhancement of the rule of law and to the protection of citizens' rights was both much easier and much more effective. In turn, this complementarity made it possible to offer citizens a broader range of choice when it came to choosing between alternative mechanisms of redress and deciding on how best to exercise these rights. As such, this complementarity, which has allowed the ombudsman to assume the status and the moral authority of what the French aptly call a "magistrature d'influence", has also positively contributed to the quality of democracy in countries where 
such arrangements obtain. ${ }^{15}$

In the obverse scenario, where democracy was introduced in countries where the rule of law tradition was weak, fragile, or, in the worst of cases, simply lacking, the prospects for the ombudsman to serve as an effective mechanism of accountability and to contribute to the deepening of both rule of law and democracy have been less bright. Where democracy cannot count on the norms and values associated with the culture of respect for reciprocal rights and obligations generated by the rule of law, and where, as consequence, the courts cannot effectively serve as the cornerstone for the construction of a system of institutional checks and balances and of a dense network of counterweights, the power of the executive branch of government and, more generally, of the state can easily remain unrestrained. Such an environment is almost by definition inhospitable for the ombudsman institution and severely circumscribes its capacity to serve as an effective mechanism of control and accountability, capable of protecting the rights of citizens.

In such circumstances, the ombudsman is faced with the unenviable prospect of becoming marginalised and potentially ignored. The likely end result of such an eventuality is the gradual delegitimation of the institution, as its incapacity to serve its avowed purpose leads to the erosion of its moral authority and robs it of its raison d'être. The same outcome may also obtain in cases where the uncritical reading of, and borrowing from, ombudsman models derived from qualitatively different historical circumstances and temporal sequences generates unrealistic expectations concerning the ombudsman's capacity to serve as a mechanism of control capable of holding the executive branch of government accountable in countries where the rule of law is tenuous, fragile, or simply non-existent. Illustrative examples of such an eventuality are observable in certain of the new democracies in Southeastern Europe, where, in the absence of any meaningful counterweights to the power of the executive branch of government, calls have been made for the ombudsman institution to be equipped with prosecutorial powers, similar to those enjoyed by the Swedish and Finnish ombudsmen. Such a course of action, which is based on a misreading of the vastly different historical circumstances and temporal sequences that gave rise to the ombudsman institution in these two Scandinavian countries, fails to appreciate the dangers to the very viability to the ombudsman institution in these recent democracies likely to result from the involvement of the institution in what are bound to become political conflicts and struggles centring on its efforts to rein in an executive culturally and politically resistant to all forms of restraint. ${ }^{16}$

Let me now attempt to apply the preceding theoretical schema on concrete historical reality and to demonstrate its utility to contemporary Europe. In line 
with the logic of the first scenario, in which the rule of law historically precedes the introduction of democracy, I would argue that a better and more hospitable environment for the establishment and development of the ombudsman institution and for its capacity to serve as an effective mechanism of accountability and control, once democracy was introduced and a modern democratic state was constructed, obtained initially in Western and Northern Europe. A direct outcome of this combination of historical factors was the fact that, between 1809 and 1972, the institution was established exclusively in these areas and, by extension, in one of the countries (New Zealand) belonging to the British Commonwealth.

A similar argument can, mutatis mutandis, be made for the successor states (and even regions) of the Austria-Hungarian Empire, where the rule of law became well entrenched from the mid-18th century on, receiving great impetus during the golden half century (1740-1790) of Maria Theresa's and Joseph II's reigns, and where familiarisation with democratic practices dated to the interwar period in the $20^{\text {th }}$ century. The role which the ombudsman has, despite the legacies of the recent totalitarian experience, been able to play over the past decade or so in the construction of modern democracies in Poland, Hungary, the Czech Republic, Slovenia, and, more recently, Slovakia provides strong empirical evidence in support of this argument. ${ }^{17}$

Southern Europe constitutes an interesting hybrid case. The precocious introduction of parliamentary institutions in the region in the early decades of the $19^{\text {th }}$ century, before, that is, the rule of law had had an opportunity to become entrenched, did not contribute to the emergence of conditions favourable to the development of political regimes capable of fairly balancing the logic of equality with that liberty within the context of their respective institutional arrangements. The result was political conditions inhospitable to checks and balances and to the culture of institutional counterweights associated with it. The most immediate and visible by-product of these conditions was the seemingly endless oscillation between authoritarian rule and unstable and ultimately failed democratic regimes that so profoundly marked the region well into the first half of the $20^{\text {th }}$ century. ${ }^{18}$

Two developments served as the catalyst that made it possible to escape from the vicious cycle of failed democratic experiments and authoritarian interludes: the political learning derived from the traumatic experiences associated with the authoritarian regimes which prevailed in the region in the interwar and post-war periods and the profound influence, by way of a demonstration effect, which, beginning in the 1960s, the European Economic Community, now the European Union, was able to exercise over political elites and masses in the countries of the region. As a result, the democratic regimes established in the mid-1970s were able to provide for a fair balance of institutional arrangements expressive of rule of 
law and democracy. It was in this, more hospitable setting, that the ombudsman institution emerged as part of the institutional arsenal of what, for the first time in the modern histories of the countries in the region, became consolidated modern democracies. ${ }^{19}$

In marked contrast to the preceding analysis stand the successor states of the Ottoman Empire in Southeastern Europe. In this region, where, (a) again for historical reasons, the state retained to the very end, in the early 20th century, its highly patrimonial character and the rule of law never acquired deep roots; where, (b) as a result of long periods of authoritarian and totalitarian rule, familiarity with democratic practices ranged from the very limited to the non-existent; and where (c) the introduction of democratic practices effectively coincided with, if it did not precede, efforts to establish, the rule of law, the challenges facing the ombudsman institution as its seeks to carve out its proper role within the institutional landscape of its respective democratic regime are formidable. The experiences of ombudsmen in Southeastern Europe to date constitute telling evidence of the much more tortuous road the institution will have to travel on its way to becoming an effective instrument of control and accountability capable of substantively contributing to the defence of citizens' rights and to the quality of democracy in each country in the region. ${ }^{20}$

Let me conclude with two final observations. The first recalls the point made at the beginning of this article concerning the impossibility of solving issues relating to the legitimacy of the state from within democracy, by making use of the majoritarian principle. This observation has special relevance to all the more recent European democracies facing problems in accommodating minorities into their democratic systems, and is especially pertinent to states where minorities are particularly large. It also forcefully highlights the more general point, also made earlier, that, in certain instances, questions relating to the rule of law, such as the defence of human rights, cannot be resolved by having recourse to the majoritarian logic of democracy. Hence the need for the balanced development of both, if the interests of citizens are to be well served by a modern democratic state. ${ }^{21}$

The second observation concerns ombudsmen in the European Union and, more specifically, the challenges they have to face as they try to promote the rule of law and democracy at their respective levels within the Union. I remain deeply convinced that success in this difficult task is only possible, when ombudsmen at all levels of governance, European, national, regional or local, effectively collaborate and coordinate their efforts, with an eye to serving citizens better. It is for this reason that both my predecessor, Jacob Söderman, and I attempted to convince the Convention for the Future of Europe and the ensuing Intergovernmental 
Conference to include in the draft constitutional treaty an explicit recognition of the rights of European citizens to have access to ombudsmen and other nonjudicial means of redress, when seeking to defend their rights.

Even though the final text of the constitutional treaty did not contain a provision to that effect, the strengthening of non-judicial means of redress, as alternatives to judicial ones, must remain a strategic goal for the ombudsman community within the Union. Success in this direction would not only make it easier for all ombudsmen and similar bodies to help citizens know their rights better and to also better enjoy their rights. It would also substantively enhance the capacity of ombudsmen, whether at the European national, regional or local levels, to contribute to the deepening of the rule of law and to the improvement of the quality of democracy at all levels of the Union. And that certainly constitutes a goal well worth pursuing.

\section{ENDNOTES}

1 - For illustrative examples of recent works on the divisions brought about by the European "civil wars" of the $20^{\text {th }}$ century, see, among others, Mark Mazower, Dark Continent: Europe's Twentieth Century (London: Allen Lane, the Penguin Press, 1998) and Norman Davies, Europe: A History (London: Pimlico, 1997).

2 - For a theoretical treatment of the importance of sequences in political development and state-building efforts, see Leonard Binder et al., Crises and Sequences in Political Development (Princeton, NJ: Princeton University Press, 1971).

3 - For a classic statement on the rule of law, see A. V. Dicey, Introduction to the Study of the Law of the Constitution (London: Macmillan, 1961), 183-205 and passim. See also David Lindsay Keir, The Constitutional History of Modern Britain since 1485 (Princeton, NJ: Van Nostrand, 1963), 293-98; Harold J. Laski, Parliamentary Government in England (London: Allen and Unwin, 1963), 360-87 and Andre Mathiot, The British Political System (London: Hogarth Press, 1958), 195-204. For more recent analyses focusing on the relationship between the rule of law and democracy, see Guillermo O'Donnell, "Why the Rule of Law Matters," Journal of Democracy 15:4 (October 2004), 32-46 and José Maria Maravall and Adam Przeworski, eds., Democracy and the Rule of Law (Cambridge: Cambridge University Press, 2003). For a recent work linking democracy and the ombudsman, see Andreas Ch. Takis, "Ombudsmanship, Human Rights, and the Rule of Law," in Dimitris Christopoulos and Dimitris Hormovitis, eds., The Ombudsman in SouthEastern Europe (Athens and Brussels: Sakkoulas and Bruylant, 2005), 152-57. 
4 - For Weber's treatment of legal-rational rules as a quintessential dimension of the modern state, see Max Weber, Economy and Society, edited by Guenther Roth and Claus Wittich, (Berkeley, CA: University of California Press, 1978), 213-26 and passim. On the significance of a legal- rational tradition for democratic regimes, see Yossi Shain and Juan J. Linz, Between States: Interim Governments and Democratic Transitions (Cambridge: Cambridge University Press, 1995), 10-14.

5 - For Montesquieu's treatment concerning the mediated exercise of power and the concept of "corps intermédiaires", see Baron de Montesquieu, The Spirit of the Laws (New York: Hafner, 1962), 66-70 and 120-25.

6 - For a classic statement on the historical upheavals that gave rise to modern democracy, see Robert R. Palmer, The Age of Democratic Revolution: A Political History of Europe and America, 1760-1800, 2 vols., (Princeton, NJ: Princeton University Press, 1959). For a distinguished political science treatment of modern democracy, see Robert A. Dahl, Democracy and its Critics (New Haven, CT: Yale University Press, 1989). For a celebrated work examining the relationship between ancient and modern democracy, see Benjamin Constant, "De la liberte des anciens à celle des modernes," in idem Cours de politique constitutionelle ou collection des ouvrages publiès sur le gouvernement représentatif (Paris: Guillaumin, 1872), vol. 2, 539-60.

7 - The political science literature on democracy abounds with various definitions ranging from minimalist to highly exacting, complex and maximalist conceptualisations. For illustrative examples of works adopting a perspective similar to the one used here, see, among others, Dahl, Democracy and its Critics, 108-15 and passim; Juan J. Linz, "Totalitarian and Authoritarian Regimes," in Fred I. Greenstein and Nelson W. Polsby, eds., Handbook of Political Science, vol. 3 (Reading, MA: Addison Wesley, 1975), 182-83; and Richard Gunther, P. Nikiforos Diamandouros and Hans-Jürgen Puhle, eds., The Politics of Democratic Consolidation: Southern Europe in Comparative Perspective (Baltimore, MD: Johns Hopkins University Press, 1995), 5-7. On"veto groups," see Scott Mainwaring, Guillermo O'Donnell and J. Samuel Valenzuela, eds., Issues in Democratic Consolidation: The New South American Democracies in Comparative Perspective (Notre Dame, IN: University of Notre Dame Press, 1992), 48-49.

8 - On electoral regimes, see Terry Lynn Karl, "Imposing Consent? Electoralism vs. Democratization in El Salvador," in Paul Drake and Eduardo Silva, eds. Elections and Democratization in Latin America, 1980-85 (San Diego, CA: Centre for Iberian and Latin American Studies, 1986), 9-36. For a more recent conceptualisation focusing on the more general issues raised here, see Wolfgang Merkl, "Embedded or Defective Democracies," as well as Merkl and Aurel Croissant, "Conclusion: Good and Defective Democracies," Democratization 11:5 (December 2004), 33-58 and 199-213 respectively. 
9 - On the relationship between democracy and the legitimacy of the state, see Dahl, Democracy and its Critics, 207, as well as Juan J. Linz and Alfred Stepan, Problems of Democratic Transition and Consolidation: Southern Europe, South America, and Post-Communist Europe (Baltimore, MD: Johns Hopkins University Press, 1996), 26-33 and passim.

10 - For a discussion of majoritarian democratic systems and of their dynamics, see Arend Lijphart, Patterns of Democracy. Government Forms and Performance in Thirty-Six Countries (New Haven, CT: Yale University Press, 1999), 9-30.

11 - For the concept of "levelling egalitarianism" as applied to one particular country, see P. Nikiforos Diamandouros, "Cultural Dualism and Political Change in Postauthoritarian Greece," (Madrid: Juan March Centro de Estudios Avanzados en Ciencias Sociales, 1994, Working Paper 50), 14 and passim.

12 - Recent research on democratisation is paying increasing attention to the notion of "quality of democracy." For illustrative examples of recent scholarly attempts to treat the subject systematically, see Leonardo Morlino, "What is 'Good' Democracy?", Democratization 11:5 (December 2004), 10-32; Guillermo O'Donnell, Jorge Vargas Cullell, and Osvaldo M. lazzetta, eds., The Quality of Democracy: Theory and Applications (Notre Dame, IN: University of Notre Dame Press, 2004), and, in addition to the article by O'Donnell cited in note 3 above, the contributions by Diamond and Morlino, Schmitter, Beetham, Rueschemeyer, Powell, and Plattner devoted to this topic in Journal of Democracy 15:4 (October 2004). 20-110.

13 - On the ombudsman as part of the institutional arsenal of modern democratic states, see Andreas Schedler, Larry Diamond and Marc F. Plattner, eds., The SelfRestraining State: Power and Accountability in New Democracies (London: Lynne Rienner, 1999). Over the past few decades, the Danish Ombudsman has increasingly come to be regarded as the quintessential parliamentary ombudsman institution and to exercise powerful influence in the international community as the paradigm to be emulated. For a recent work in English focusing on the history and evolution of this institution, see Hans Gammeltoft-Hansen and Jens Olsen, eds., The Danish Ombudsman 2005 (Copenhagen: Folkentingets Ombudsmand, 2005). See also the broad overview on the subject offered by Hans GammeltoftHansen, the incumbent ombudsman of Denmark and the longest serving ombudsman in the world as of 2005, in The European Ombudsman: Origins, Establishment, Evolution (Luxembourg: Office for Official Publications of the European Communities, 2005), 13-26.

14- If Sweden, where the ombudsman was established in 1809, constitutes the classic example of a country where the sequence just described most visibly obtained, the Nordic countries, as well as those, including the United Kingdom, 
belonging to the British Commonwealth also provided fertile ground for the early establishment and firm rooting of the institution. It is not, therefore, accidental that, until the so-called "third wave" of democratisation set in during the mid1970s, the ombudsman institution had been successfully established and taken roots in only seven countries, six of which (Sweden [1809], Finland [1919], Denmark [1955], New Zealand and Norway [1962] and the United Kingdom [1967] fall squarely within this broad category. For the concept of the "third wave" of democratization, see Samuel P. Huntington, The Third Wave: Democratization in the Late Twentieth Century (Norman: University of Oklahoma Press, 1991).

15- On the issue of democratic accountability, see Andreas Schedler, "Conceptualizing Accountability," Guillermo O'Donnell “Horizontal Accountability in New Democracies," and Philippe C. Schmitter "The Limits of Horizontal Accountability" in Schedler, Diamond, and Plattner, eds., The Self-Restraining State, 13-28, 29-52, and 59-62 respectively. See also Leonardo Morlino, "What is 'Good' Democracy?" passim.

16 - For a critical analysis of the dangers implicit in such a conceptualisation of the ombudsman leading to its potential overload, see Dimitris Christopoulos and P. Nikiforos Diamandouros, "Traditional Rights Protection Mechanisms and the Rising Role of Mediation in South Eastern Europe," in Christopoulos and Hormovitis, eds., The Ombudsman in South eastern Europe, 30-40.

17 - For an elaboration of this point as concerns the successor states of the AustriaHungarian Empire, see P. Nikiforos Diamandouros and F. Stephen Larrrabee, "Democratization in South-Eastern Europe: Theoretical Considerations and Evolving Trends," in Geoffrey Pridham and Tom Gallagher, eds., Experimenting with Democracy: Regime Change in the Balkans (London: Routledge, 2000), 2464.

18 - For a historical analysis dealing with the oscillation between authoritarianism and unstable and ultimately failed democratic experiments in Southern Europe since the end of the Napoleonic Wars, see Edward E. Malefakis, "The Political and Socioeconomic Contours of Southern European History," in Gunther, Diamandouros, Puhle, eds., The Politics of Democratic Consolidation, 33-76.

19 - The systematic study of the nature and consequences of the establishment of stable, consolidated democratic regimes in Southern Europe over the past half century or so constitutes the focus of the five volume series produced under the auspices of the "Subcommittee on Southern Europe" of the American Council of Learned Societies and the Social Science Research Council (New York). For analyses pertinent to the concerns of this article, see, in addition to The Politics of Democratic Consolidation, already cited, P. Nikiforos Diamandouros and Richard Gunther, eds., Parties, Politics, and Democracy in the New Southern Europe 
(Baltimore, MD: Johns Hopkins University Press, 2001), and Richard Gunther, P. Nikiforos Diamandouros and Dimitri A. Sotiropoulos, eds., Democracy and the State in the New Southern Europe (forthcoming).

20 - On the prospects for democracy in the successor states of the Ottoman Empire, see Diamandouros and Larrabee, "Democratization in South-Eastern Europe," 24-64.

21 - For a theoretical discussion of the problems associated with an attempt to solve issues relating to the rule of law by having recourse to the majoritarian logic of democracy, see the works by Dahl (1989) and Linz and Stepan (1996) cited in note 9 above. 
Democracy, Rule of Law, and the Ombudsman 


\section{DEMOKRASI, HUKUKUN ÜSTÜNLÜĞÜ VE OMBUDSMANLIK KURUMU(1)}

\section{P. Nikiforos DIAMANDOUROS(2)}

Genişleyen Avrupa Birliği, yeniden birleşme süreciyle birlikte yeni keşfedilen gerçekliklere ve dinamiklere kademeli olarak uyum sağlamaktadır. Bu, Avrupa'da 20. yüzyılda meydana gelen iç savaşlardan kaynaklandığını düşündüğüm büyük, travmatik ve derin bölünmelerin siyasi ve sembolik olarak sona erdiğini göstermektedir. Dolayısıyla, Ombudsmanlık Kurumunun vatandaşlara hizmet edebilme ve vatandaşların haklarını daha iyi kullanabilmelerini sağlayabilme yetisini doğrudan etkileyen daha geniş çaplı siyasi ve kurumsal bağlamları ele almak uygun olabilir, doğrusunu söylemek gerekirse bu yerinde ve doğru yaklaşım olur. Bu durumu derinden etkileyen ve şekillendiren iki önemli parametre bulunmaktadır. Bunlar, hukukun üstünlüğü ve demokrasidir. Bu iki parametre ve Ombudsmanlık Kurumu arasındaki etkileşim bu kısa makalenin konusunu oluşturmaktadır. ${ }^{1}$

Öne sürdüğüm argüman, hukukun üstünlüğü ve demokrasi ilkelerinin belirli bir topluma getirildiği belirli bir zamanda vukubulan ve gelişen hadiseler dizisinin, Ombudsmanlık Kurumunun faaliyet göstereceği siyasi ve kurumsal ortamı doğrudan etkilemesi ile alakalıdır. Dahası, hukukun üstünlüğünün demokrasiden önce gelmesi halinde ortaya çıkan siyasi, kurumsal ve kültürel çevrenin, Ombudsmanlık Kurumunun potansiyelini tam anlamıyla kullanmasına daha açık hale geleceği ve bu kurumun vatandaşların maddî (usulî olmayan) ve somut kurallar itibariyle güçlendirilmesine katkı sağlayan bir mekanizma olarak hizmet etmesini kolaylaştıracağı hususunu belirtmek isterim. Buna karşılık, demokrasinin ortaya çıkışının hukukun üstünlüğünden önce olduğu veya aynı döneme denk geldiği tam tersi yöndeki olaylar dizisi, vatandaşlara haklar verilerek vatandaşların güçlendirilmelerine ilişkin bakış açısıyla ele alınırsa bu durum alt-optimal bir seçenek görevi görmektedir. Yazımın devamında bu argümanı daha sistematik bir şekilde geliştirmeye çalışacağım. ${ }^{2}$

Açıkça ortaya konmuş bir hususu vurgulayarak başlayayım yazıma. Çağdaş Avrupa hukuk kültüründe hukukun üstünlüğü ve demokrasinin ayrılmaz bir bütün, tabiri caizse doğal bir çift olduğu düşünülse de bu kavramlar belirgin bir şekilde birbirinden ayrılmaktadır ve analitik olarak birbirinden farklıdır.

(1) Bu makale orjinal olarak “Hans Gammeltoft-Hansen and Jens Olsen, eds., The Danish Ombudsman 2005-Part III, (Copenhagen: Folketingets Ombudsmand, 2005), 11-22." yayınlanmıştır.

(2) Avrupa eski Ombudsmanı 
Hukukun üstünlüğü, bir toplumun tüm üyelerinin hukuka uygun yaşadığı ve hiç kimsenin hukukun dışında veya üstünde olmadığı bir durumu anlatır. Bu kavramın tarihsel kökenleri, Avrupa feodalizminden ve zamanla efendi ve köleyi birbirine bağlayan sözleşmeye dayalı ilişkilerden kaynaklanan karşılıklı hak ve yükümlülüklerin sıkı ve karmaşık bağlantısından gelmektedir. Hukukun üstünlüğü ilkesi kapsamında yer alan herkesin, olağanüstü veya istisnai düzenlemelere değil olağan hukuka tâbi olduğuna ilişkin sonradan eklenen ilke doğrudan böyle bir durum sonucu ortaya çıkmıştır. Hukukun üstünlüğünün ortaya çıkması ve varlığının desteklenmesi ile ilgili önemli bir husus da, bu kavramın genel prensiplerinin ister istemez yargı kararlarına bağlı olarak ortaya çıktığıdır. Diğer bir deyişle, mahkemeler hukukun üstünlüğü ilkesinin dayandırıldığı ve gelişim ve evriminin bağlı olduğu temeli oluşturmaktadır. Son olarak, hukukun üstünlüğü ile ilgili sadece temel niteliklerden bahsedecek olursam, tanımı gereği hukukun üstünlüğü, yürütme yetkisinin sınırsızca kullanımının (potansiyel olarak keyfi kullanımının) söz konusu olmaması demektir. Bu kavramın tanımı Latin atasözünde zarif bir şekilde verilmiştir "Quod principi placuit, legis habet vigorem" (hükümdarı memnun eden ne varsa hukukun gücünü de elinde bulundurur). Hükümdarın isteklerine olağanüstü değer veren bu görüş, uzun süre mutlak hükümetin entelektüel gerekçesi ve destekleyicisi olarak hizmet etmiştir. ${ }^{3}$

Hukukun üstünlüğü ile ilgili bir başka konu da, bu üstünlüğün kabul edilmesiyle nitelendirilen koşullar altında, devletin anayasasının Max Weber'in "Yasal rasyonel" kurallar olarak tanımladığı temel üzerine inşa edilmesidir. Bu da, tanınan yetkilerin ve devletin hukuki temelini oluşturmaktadır. ${ }^{4}$

Son olarak, hukukun üstünlüğü ilkesinin evrimi zamanla sosyal ve siyasal düzenlemeleri de beraberinde getirmiştir. Bunların ayırt edici özelliği ise yönetenler ile yönetilenler arasındaki ilişkinin doğrudan ve anında olmaması, yasal olarak tanınan ve yetki verilen yapı veya kurumlar tarafından yönlendirilmesidir. Bu da, yönetici tarafından icra edilen yetkilere etkili sınırlar getirmektedir. Hukukun üstünlüğü ve ilişkilendirildiği dolaylı yetki kullanımı örneğinin bu özelliği, Montesquieu tarafından "Spirit of the Laws" adlı çalışmasında zekice ifade ettiği "corps intermédiaires (aracı kurumlar)" terimi kapsamında ele alınmış ve geniş ölçüde analiz edilmiştir. ${ }^{5}$

Daha eskilere dayanan hukukun üstünlüğü kavramının aksine demokrasi kavramı, çok daha yeni bir olgudur. 18'inci yüzyılın son çeyreğinde başlayan ve 20'nci yüzyıla kadar süren "uzun yüzyılda" Avrupa Kıtası ve Amerikan kolonilerini sarsan siyasi ve sosyo-ekonomik çalkantılarla ayrılmaz bir biçimde bağlantılıdır. Tebaadan vatandaşığa geçen gittikçe daha fazla kişiye verilen oy hakkının kademeli olarak artması ile ilişkilendirilen demokrasi ve özellikle bu kavramın serbest değişkeni günümüzde sadece Avrupa'da değil (bu, dolaylı olarak 
makalemin odak noktasını oluşturmaktadır), aynı zamanda tüm dünyadaki ülkelerin büyük çoğunluğunda tartışmasız meşruiyete sahiptir. ${ }^{6}$

Demokrasinin tanımları, uzun ve ayrıntılı olabilir. Bu analizin amaçları doğrultusunda, sade (minimalist) bir kavramlaştırma yöntemini benimsemeyi ve yalnızca demokrasinin meşruiyetine ve etkinliğine ilişkin temel önkoşulları oluşturan bazı temel niteliklerini tanımlamayı tercih ediyorum. Bana göre bunlar arasında (a) adil seçimlerin yapılmasına olanak sağlama kapasitesi, (b) bir seçime serbestçe itiraz etme hakkına sahip birden fazla yasal partinin varlığı, (c) siyaset bilimcilerinin deyimiyle demokratik sürece müdahale etme yetkisine sahip olan ve oy kullananların kararlarını her şekilde devre dışı bırakan veya geçersiz kılan "veto gruplarının" yokluğu gibi temel nitelikler yer almaktadır. Bu veto gruplarının geleneksel örnekleri arasında monarşi, silahlı kuvvetler veya devletin diğer unsurları bulunmaktadır. Bunlar, halkın oylarıyla verilen bir seçim kararını saygı duyulması gereken meşru ve nihai bir karar olarak görmek istemezler.?

Böyle bir kavramlaştırmada kastedilen önemli husus, demokrasinin sadece parlamento kurumları veya sadece seçim yapılması ile eşdeğerde olmayacağıdır. Günümüzde dünyanın, geçmişte de Avrupa'nın pek çok yerinde parlamento kurumlarının var olması, yukarıda belirtilen demokrasinin temel özellikleri olan koşulların yeterince karşılanmasını sağlamamıştır. Ayrıca, dünyaya üstünkörü baktığımızda bile pek çok ülkede seçimlerin gerçekleştirildiği koşulların, adalet, serbest rekabet ve yukarıda bahsedilen veto gruplarının yokluğu gibi kriterleri karşılamadığı görüşünü savunan çok sayıda kanıt bulmak mümkündür. Bunların demokrasiden ziyade "seçim rejimleri" olarak değerlendirilmesi daha doğru olur. $\mathrm{Bu}$ rejimlerin, demokrasinin resmi gerekliliklerini karşılama kapasitesi oldukça sınırlıdır. ${ }^{8}$

Son olarak demokrasi ve devletin meşruiyeti arasındaki ilişki ile alakalı ve bazı yönleriyle daha karmaşık olan bir hususu daha dile getireyim. Basitçe söylemek gerekirse, vatandaşlarının gözünde devletin meşruluğunun kabul edilmesi demokrasinin düzgün işlemesi için bir ön koşul oluşturmaktadır. Aslında, bu öneriyi bir adım ileri götürmek ve devletin meşru görülmediği durumlarda demokratik sürecin bu sorunu düzeltmesinin mümkün olmayacağını belirtmek isterim. Bu gözlem, yaptığım analiz ile ilgili oldukça önemli bir hususu açıklığa kavuşturmakta ve hukukun üstünlüğü ve demokrasi arasındaki önemli bir ayrımı vurgulamaktadır. Bunu vurgularken de, demokratik süreci harekete geçiren çoğunlukçu mantığın, hukukun üstünlüğü ilkesinin önceliğine ilişkin hususların ele alınmasında bir araç olarak kullanılamayacağına işaret etmektedir. Yalnızca bir örnek vereyim. Bu örneğe analizimin sonuna doğru tekrar değineceğim ve bu örnek yeni Avrupa demokrasilerinin karşılaştığı siyasi sorunlarla doğrudan ilişkilidir: demokratik süreç, diğer bir deyişle, çoğunluk ilkesi, azınlıkların hakları 
da dâhil olmak üzere insan haklarının savunulması ile ilgili sorunların çözümünde kullanılamaz. ${ }^{9}$

Bu modern çağda kısa süreli varlığı süresince demokrasiye pek çok yapı ve çeşitlilik yüklenmiştir. Sınıflandırma kriteri olarak hangi ilke veya özelliğin seçildiğine bağlı olarak demokrasiler, parlamenter, başkanlık veya yarı başkanlık şeklinde düşünülebilir. Yarı başkanlık sistemi, Beşinci Cumhuriyet yönetimi altında oluşturulan Fransız yönetim biçimine atıfta bulunmaktadır. Bunlara alternatif olarak, demokrasileri çoğunlukçu veya ortaklıkçı (uzlaşıya dayalı); ya da anayasal monarşilerin aksine cumhuriyetçi olarak değerlendirebiliriz.

Eğer sorgulamamızı demokrasiyi bilgilendiren soyut ilkelerin seviyesine çekersek, Aydınlanma çağının ve bu önemli çağın politik devrimlerinin ortaya çıkardığı en güçlü iki entelektüel miras olan eşitlik ve hürriyetin, bütün modern demokrasilerin kurulurken temel aldığı sağlam birer zemin görevi gördüklerini iddia edebilirim. Anayasal bir formüle entegre edilen ve kurumsal düzenlemelerle sonlanan bu iki ilke arasındaki nispi denge, demokrasi ile ve özellikle Avrupa'da ve ötesindeki demokrasinin kalitesi ile ilgili olan çağdaş entelektüel ve politik münazaralar üzerinde özellikle etkisi olan modern demokrasinin iki değişkenini birbirinden ayırmamıza olanak sağlar.

Fransız İhtilali'nin Jakoben mirasından köklerini alan ilk değişken, eşitliği demokrasinin gerekli organizasyon ilkesi olarak görüp ona ayrıcalık tanır. Bunun çekiciliği, sadeliğinden kaynaklanan zarifliğinde yatar. Demokrasinin kavramsallaştırımasına göre, en temel hatlarına ayrılmış şekilde, tek kurumsal ifadeleri parlamento (çoğunlukla tek meclisli) olan egemen insanlar gücün yegane kaynağını oluştururlar. Tek partili kabine oluşturabilen çoğunlukçu sistemlerde, çoğunluğa sahip olan parti popüler egemenliğin mantıklı ve doğal yegâne tanımını oluşturur ve bu sebepten dolayı, egemen insanların adına yetki kullanma haklarını yasal bir şekilde iddia edebilirler. ${ }^{10}$

Demokrasinin böylesine eşitlikçi bir biçimde kavramsallaştııımasının bariz avantajlarına rağmen, eşitliği tek olmasa da başlıca organizasyon ilkesi olarak görmesinden kaynaklanan önemli bir kusuru, homojenliği çeşitlilikten üstün görmesine bağlı ortaya çıkan "tek boyutluluk" mantığı olarak adlandırabileceğim bir şey tarafından yönlendirilmesidir. Mantıksal uç noktaları zorlandığında, eşitlikle çok yakından alakalı olan homojenliğe vurgu yapmak, onun dayanağını oluşturan tek boyutluluk mantığı ile ilişkilendirilen demokrasiye "eşitliği seviyelendirme" boyutu katabilen yassı bir dinamik oluşturma riskini ortaya çıkarır. Dolayısıyla, demokrasinin bu şekilde kavramsallaştırılması, hukukun üstünlüğüne riayet edilmesi ve haklardan faydalanmaya ve buna bağlı zorunluluklara saygı konusunda ciddi endişeler ortaya çıkarır. ${ }^{11}$

Eklemek için sabırsızlandığım diğer değişken ise, son yıllarda dikkat çekiyor ve 
kopyalaması gittikçe popüler olan, eşitlik ve özgürlük ilkelerinin çeşitli bileşimlerini bütünleştirme becerisine sahip kurumsal düzenlemelerin kurulmasının sistematik arayışı ile nitelendirilen ilginç bir paradigma görevini üstleniyor gibi görünüyor. Demokrasinin bu kavramsallaştırılmasını yönlendiren şey, başlıca kaygısı karşılıklı olarak eşitlikçi ve özgürlükçü ilkeleri anlatan kurumlar arasındaki optimum denge arayışı olan çoğunlukçu mantıktır. Yoğun bir kurumsal güçler ayrılığı ya da Montesquieu'nün "aracı kurumlar" ile ilgili olan dengeleyen unsur ağının oluşturulmasına bağlı olan böylesine kapsayıcı bir denge, zaman içinde kristalleşmesi, sağlamlaşması ve birleşmesi sayesinde hukukun üstünlüğüne riayet edilmesi ve demokrasinin kalitesinin artırılması için daha iyi koşullar sağlar. ${ }^{12}$

Bu yüzden, yargı organının güçler birliği ilkesinin kaynağı olarak, en gelişmiş ve saygıdeğer rolünün ve böylesine bir denge ağırlığının tipik örneği olarak Ombudsmanın onaylanmasının bu değişkene en yakın anlamda olan demokrasilerde olması bir tesadüf değildir. Kısaca, ilk olarak İsveç'te 1809 yılında kurulan ve daha sonra sırayla 1919'da Finlandiya'ya, 1955'te Danimarka'ya ve 1962'de Norveç'e ve Yeni Zelanda'ya yayılan Ombudsmanlık Kurumu şimdi ulusal düzeyde Avrupa Birliği'nin 25 üye ülkesinin 23'ünde (İtalya ve Almanya'da yerel ve bölgesel düzeyde) ve Güneydoğu Avrupa'nın sekiz devletinden yedisinde varlığını sürdürmektedir ve hukukun üstünlüğü ile demokrasinin kalitesinin artırılmasına yönelik uygulamaları ve kaideleri ile çok yakından tanımlanır. ${ }^{13}$

Önceki analizleri göz önüne alırsak, neredeyse kendiliğinden ortaya çıkan sorular şunlardır: hangi hukukun üstünlüğü ve demokrasi bileşeni, Ombudsmanın kötü yönetimle savaşmasına, vatandaşların haklarını savunmasına ve insan haklarını korumasına izin veren kurumsal bir dengeleyici unsur olarak daha iyi hizmet vermesi için daha ılımlı bir ortam sağlayabilir? Daha çok anlaşılsın diye, bir şekilde sistemli olmayı ve bu soruna yeterli çözüm olabilecek senaryoları ya da öylesine ikili bileşenleri bulmayı öneriyorum. ìlk olarak, genellikle daha olgun demokrasilerde tipik olduğu gibi, hukukun üstünlüğünün ortaya çıkması tarihsel olarak demokrasiden önce geldi. Bu tür durumlarda, rasyonel-yasal kanunlar çerçevesinde düzenlenen devletin inşasının temel dayanağı olan hukukun üstünlüğünün önce var olması kaçınılmaz gerginliklerle, türbülansla ve her ülkede demokrasinin tanıtılmasına bağlı popüler katılımın artmasıyla bağdaşan ara sıra meydana gelen kargaşalarla yüzleşmeyi kolaylaştırmıştır. ${ }^{14}$

Hukukun üstünlüğünün ve demokrasinin olumlu dile getirilmesiyle sonuçlanan bir etkinin süregeldiği ülkelerde, mahkemelere ek olarak, fakat onlardanfarklıolarak hukukun üstünlüğü ve vatandaşların haklarının korunmasının genişletilmesiyle alakalı kontrol ve hesap verebilirliğin yargısal olmayan mekanizması olarak işlev gösterme gücüne sahip Ombudsmanlık Kurumunun ortaya çıkması hem daha kolay hem de çok daha etkili olmuştur. Dolayısıyla, bu tamamlayıcılık vatandaşlara, 
alternatif telafi mekanizmaları ve bu hakları en iyi şekilde kullanmaya karar verme arasında seçim yapmaları için geniş seçenek yelpazesi sunmayı mümkün kılmıştır. Böylece, Fransızların doğru bir şekilde "etki yargıcı" olarak adlandırdıkları ahlaki otoriteyi ve statüyü kazanmasına imkân sağlayan bu tamamlayıcılık, böyle düzenlemelerin süregeldiği ülkelerdeki demokrasi kalitesine olumlu katkılarda bulunmuştur. ${ }^{15}$

Hukukun üstünlüğü geleneğinin zayıf, hassas olduğu veya hiç olmadığı ülkelerde demokrasinin tanıtılığı diğer senaryoda ise, Ombudsmanın hukukun üstünlüğünün ve demokrasinin derinleştirilmesine katkıda bulunması ve sorumluluk mekanizması görevini üstlenmesi için gerekli beklentiler daha azdı. Demokrasinin, karşılıklı haklara saygı kültürüyle bağdaşan değerlere ve kaidelere ve hukukun üstünlüğü ile ortaya çıkan zorunluluklara güvenemeyeceği yerlerde ve bunun sonucunda, mahkemelerin kurumsal güçler ayrılığı veya dengeleyici unsur ağı sisteminin inşasında etkili bir şekilde temel taşı olarak hizmet veremediği yerlerde, hükümetin, daha da genellersek, devletin yürütme organı çok kolay bir şekilde zapt edilemeden varlığını sürdürür. Böylesine bir ortam Ombudsmanlık Kurumu için neredeyse tamamen istenmeyen bir ortamdır ve ombudsmanın vatandaşların haklarını koruma gücüne sahip etkili bir kontrol ve sorumluluk mekanizması olarak çalışma imkânını ciddi bir şekilde kısıtlar.

Bu gibi durumlarda, Ombudsmanlık Kurumu marjinalleştirilme ve potansiyel olarak ihmal edilme gibi hoş olmayan ihtimallerle karşı karşıya kalmaktadır. Böyle bir olası durum, kurumun kademeli olarak meşruluğunu yitirmesiyle meydana gelmektedir. Ombudsmanlık kurumunun açıkça belirtilen amaçlara hizmet edememesi, ahlaki otoritesinin sarsılmasına zemin hazırlar ve var olma nedenini ortadan kaldıır. Niteliksel olarak farklı tarihsel koşullar ve dönemsel olaylar sonucu ortaya çıkmış ombudsmanlık modellerinin alınmasının veya bu modellerin eleştirel bir yaklaşımla ele alınmamasının, hukukun üstünlüğü ilkesinin çok zayıf, kırılgan bir yapıda olduğu veya hiç var olmadığı ülkelerde Ombudsmanlık Kurumunun buralardaki sorumlu hükümetlerin yürütme organı görevini görmesi ve kontrol mekanizması olarak hizmet etme kapasitesi ile ilgili olarak gerçekçi olmayan beklentilerin oluştuğu durumlarda aynı sonuçlar ortaya çıkabilir. Böyle bir olasılığa ilişkin açıklayıcı örneklere, Güneydoğu Avrupa'daki bazı yeni demokrasilerde rastlanabilir. Hükümetin yürütme yetkisini anlamlı bir şekilde dengeleyecek bir gücün olmadığı hâllerde Ombudsmanlık Kurumunun, İsveç ve Finlandiya Ombudsmanları tarafından icra edildiği şekilde savcılık yetkileriyle donatılması istenmiştir. Bu iki İskandinav ülkesinde Ombudsmanlık Kurumunun oluşumuna zemin hazırlayan, çok farklı tarihsel koşulların ve dönemsel olayların yanlış yorumlanmasını temel alan bu tür bir yaklaşım tarzı, son dönemde ortaya çıkan demokrasilerde Ombudsmanlık Kurumunun ayakta kalabilme kapasitesine tehlike oluşturduğunu anlayamamaktadır. Bu tehlikeler, kurumun, kültürel ve 
siyasi olarak tüm kısıtlama türlerine karşı duracak şekilde yürütme görevini icra etme çabalarını merkeze alan siyasi ve politik çatışmalara ve mücadelelere müdahale etmesinden kaynaklanabilir. ${ }^{16}$

Şimdi de yukarıda gösterilen teorik şemayı, somut tarihsel gerçekliklere uygulamaya ve çağdaş Avrupa'ya olan yararlarını göstermeye çalışalım. Hukukun üstünlüğünün tarihsel olarak demokrasinin başlangıcından önce olduğu ilk senaryodaki mantık doğrultusunda, demokrasi ortaya çıktığında ve ilk çağdaş demokratik devlet inşa edildiğinde, Ombudsmanlık Kurumunun kuruluşu ve gelişimi ve etkili bir hesap verilebilirlik ve denetim mekanizması olarak işlem görebilmesi için daha uygun ve ılımlı bir ortamın ilk olarak Batı ve Kuzey Avrupa'da var olduğu görüşündeyim. Bu tarihsel faktörlerin birleşiminin doğrudan bir sonucu da 1809 ve 1972 yılları arasında kurumun sadece bu coğrafi alanlarda ve buna bağlı olarak İngiliz Topluluğuna ait ülkelerden birinde (Yeni Zelanda'da) kurulduğudur.

Benzer bir görüş, gerekli değişikliklerin yapılması suretiyle, Maria Teresa ve II. Joseph'in hükümdarlığında (1740-1790) altın yarım yüzyıl boyunca büyük ivme yakalayan ve 18. Yüzyılın ortalarından sonra hukukun üstünlüğü kavramının iyice yerleştiği ve demokratik uygulamalara aşinalığın 20. yüzyıldaki savaş dönemine kadar dayandığı Avusturya-Macar imparatorluğunun ardılı olan devletler (hatta bölgeler) için de geçerlidir. Son yaşanılan totaliter rejim dönemlerinin kalıntılarına rağmen Ombudsmanlık Kurumunun rolü geçen on yılda veya daha fazla süre boyunca Polonya, Macaristan, Çek Cumhuriyeti ve Slovenya'nın modern demokrasilerin kurulumunda etkili olabilmiştir. Ayrıca son zamanlarda, Slovakya, bu argümanı destekleyici nitelikte güçlü gözleme dayalı kanıtlar sunmaktadır. ${ }^{17}$

Güney Avrupa ise, ilginç karmaşık bir durum ortaya koymaktadır. 19. yüzyılın başlarında, yani hukukun üstünlüğü kavramı daha yerleşme fırsatı bulamadan bölgede parlamenter kurumlar ortaya çıkmış, bu kendi kurumsal düzenlemeleri bağlamında eşitlik mantığını bu özgürlük kavramıyla adil bir şekilde dengeleyebilecek siyasi rejimlerin gelişimi için elverişli koşulların ortaya çıkmasına katkı sağlamamıştır. Sonuç olarak, kontrol etme ve dengelemenin zor olduğu ve yine kurumsal denge ağılıkları kültürünün kurumla ilişkilendirilmesinin zor olduğu siyasi koşullar ortaya çıkmıştır. Görünüşe bakılırsa, bu koşulların en acele ve görünür yanı, 20. yüzyılın ilk yarısına kadar bölgeyi derinden etkileyen otoriter rejim ile istikrarsız, nihayetinde de başarısız demokratik rejimler arasındaki bitmek bilmez dalgalanmadır. ${ }^{18}$

Meydana gelen iki geliş̧me, başarısızlıkla sonuçlanan demokratik deneyimler ve otoriter dönemlerin kısır döngüsünden kurtulmayı mümkün kılan katalizör görevi görmüştür: Savaş boyunca ve savaş sonrası dönemde bölgede hâkim olan otoriter rejimlerle ilişkilendirilen travmatik deneyimlerden elde edilen siyasal çıkarımlar ve 
1960'ların başında Avrupa Ekonomi Topluluğunun yani bugünkü Avrupa Birliğinin, özendirme etkisiyle, söz konusu bölgede yer alan ülkelerdeki siyasi elit tabakaların ve kitlelerin üzerinde bıraktığı derin etkidir. Sonuç olarak, 1970'lerin ortasında kurulan demokratik rejimler, hukukun üstünlüğünü ve demokrasiyi anlatan kurumsal düzenlemeler arasındaki adil dengeyi sağlayabilmiştir. Ombudsmanlık Kurumunun, ilk kez bölgedeki ülkelerin modern tarihlerinde sağlam modern demokrasilerin mühimmat deposunun bir parçası olarak ortaya çıkması bu ılımlı dönemde gerçekleşmiştir. ${ }^{19}$

Güneydoğu Avrupa'da Osmanlı İmparatorluğundan sonra gelen devletler, yukarıda yapılan analizin tam aksi bir durum ortaya koymaktadır. (a) yine tarihsel nedenlerden dolayı son derece ataerkil olan karakteri ve henüz hukukun üstünlüğünün derinliklere işlememesi nedeniyle 20. yüzyılın başlarında devletlerin sonuna kadar korunduğu; (b) otoriter ve totaliter yönetimlerin uzun dönem hükmetmelerinin sonucu olarak demokratik yöntemlerle olan aşinalığın çok sınırlı seviyede olduğu veya hiç olmadığı ve (c) demokratik uygulamaların ortaya konmasının hukukun üstünlüğü ile aynı döneme denk geldiği bu bölgede, ilgili demokratik rejimin kurumsal yapısı içerisinde Ombudsmanlık Kurumunun kendine uygun rol oluşturma çabası içerisindeyken karşılaştığı zorluklar aşıması zor engeller ortaya koymaktadır. Güneydoğu Avrupa'daki ombudsmanların bugüne kadarki deneyimleri, kurumun bölgedeki her ülkede vatandaşlık haklarını korumaya ve demokrasinin kalitesini artırmaya önemli ölçüde katkı sağlayan etkin bir kontrol ve hesap verebilirlik aracı olmak için çok daha zahmetli yollardan geçmesi gerektiğini gösteren kanıtlardır. ${ }^{20}$

Görüşlerimi iki nihai gözlemle sonuçlandırmak isterim. illki, devletin meşruiyetiyle ilgili sorunların çoğunluk ilkesine başvurularak demokrasi kapsamında çözümünün imkânsız olduğunu konu alan, bu makalenin başında belirtilen hususu hatırlatır. Bu gözlem, azınlıkları demokratik sisteme adapte etmekte sorunlarla karşılaşmış olan tüm yeni Avrupa devletleriyle ve özellikle azınlıkların çok olduğu devletlerle ilgilidir. Yine bu gözlem, daha önce de belirtilen genel bir hususa vurgu yapmaktadır. Bu husus, bazı durumlarda insan haklarının savunulması gibi hukukun üstünlüğü ile ilgili sorunlara, çoğunlukçu demokrasi mantığına başvurularak çözüm bulunamayacağını belirtmektedir. Dolayısıyla, vatandaşların çıkarları modern demokratik bir devlet tarafından yerine getirilecekse her ikisinin de dengeli bir şekilde gelişmesi gerekmektedir. ${ }^{21}$

İkinci gözlem, Avrupa Birliğindeki ombudsmanların özellikle de birlik içinde bulundukları düzeylerde hukukun üstünlüğünü ve demokrasiyi desteklemeye çalışırken karşılaşacakları zorluklarla ilgilidir. Avrupa'da, ulusal, bölgesel, yerel tüm yönetim düzeylerindeki ombudsmanların vatandaşlara daha iyi hizmet etmek amacıyla etkin bir işbirliği ve çaba içerisinde bulundukları takdirde bu 
zorlu görevde başarılı olmalarının mümkün olduğuna yürekten inanmaya devam ediyorum. Bu sebeple de benden önce gelen Jacob Söderman ve ben, Avrupa Birliği vatandaşlarının haklarını savunmaya çalışırken ombudsmanlara ve diğer yargısal olmayan tazminat yollarına erişim haklarının açık bir tanımının taslak anayasal antlaşmaya eklenmesi için Avrupa'nın Geleceği Konvansiyonunu ve takiben Hükümetler arası Konferansı ikna etmeye çalıştık.

Anayasal antlaşmanın nihai metni bu yönde bir hüküm içermemesine rağmen, yargısal tazminat araçlarına alternatif olarak, yargısal olmayan araçların güçlendirilmesi Birlik içindeki Ombudsman camiası için stratejik bir hedef olarak kalmalıdır. Bu yöndeki başarılar, sadece ombudsmanların değil aynı zamanda benzer organların da vatandaşların haklarını daha iyi tanımasına ve daha iyi kullanmasına yardımcı olacaktır. Aynı zamanda bu başarılar, Avrupa'nın ulusal, bölgesel veya yerel düzeylerinde hangi düzeyde olursa olsun, Ombudsmanların hukukun üstünlüğünün derinleşmesine ve Birlik içindeki bütün düzeylerde demokrasinin kalitesinin artırılmasına katkı sağlama kapasitesini önemli düzeyde arttıracaktır. Bu da kesinlikle peşinden gitmeye değer bir hedef ortaya koymaktadır.

\section{DIPNOTLAR}

1 Avrupa'daki 20.yüzyıl "iç savaşlarının" neden olduğu ayrılıklara ilişkin son zamanlarda yapılan çalışmalar ile ilgili açıklayıcı örnekler için bkz: Mark Mazower, Dark Continent: Europe's Twentieth Century (London: Allen Lane, the Penguin Press, 1998) and Norman Davies, Europe: A History (London: Pimlico, 1997).

${ }^{2}$ Siyasi gelişmelerin ve devlet kurma çabalarının art arda yapılmasının önemine ilişkin teorik bir yaklaşım için bkz: Leonard Binder et al., Crises and Sequences in Political Development (Princeton, NJ: Princeton University Press, 1971).

${ }^{3}$ Hukukun üstünlüğüne ilişkin klasik bir açıklama için bkz: A. V. Dicey, Introduction to the Study of the Law of the Constitution (London: Macmillan, 1961), 183-205 and passim.Ayrica bkz: David Lindsay Keir, The Constitutional History of Modern Britain since 1485 (Princeton, NJ: Van Nostrand, 1963), 293-98; Harold J. Laski, Parliamentary Government in England (London: Allen and Unwin, 1963), 360-87 and Andre Mathiot, The British Political System (London: Hogarth Press, 1958), 195204. Hukukun üstünlüğü ve demokrasi arasındaki ilişkiyi ele alan, son dönemde yapılan analizler için bkz: Guillermo O'Donnell, "Why the Rule of Law Matters," Journal of Democracy 15:4 (October 2004), 32-46 and José Maria Maravall and Adam Przeworski, eds., Democracy and the Rule of Law (Cambridge: Cambridge University Press, 2003). 
Demokrasi ile Ombudsmanlık Kurumunu birbirine bağlayan yeni bir çalışma için bkz: Andreas Ch. Takis, "Ombudsmanship, Human Rights, and the Rule of Law," in Dimitris Christopoulos and Dimitris Hormovitis, eds., The Ombudsman in SouthEastern Europe (Athens and Brussels: Sakkoulas and Bruylant, 2005), 152-57.

${ }^{4}$ Weber'in yasal-mantıksal kuralların, modern devletin en saf boyutu olduğuna ilişkin yaklaşımı için bkz:Max Weber, Economy and Society, edited by Guenther Roth and Claus Wittich, (Berkeley, CA: University of California Press, 1978), 21326 and passim. Demokratik rejimler için yasal-rasyonel geleneğin önemi ile ilgili olarak bkz: Yossi Shain and Juan J. Linz, Between States: Interim Governments and Democratic Transitions (Cambridge:Cambridge University Press, 1995), 10-14.

${ }^{5}$ Montesquieu'nun yetkinin aracl kurumlarla icra edilmesine ve "corps intermédiaires" ( aracı kurumlar) kavramına ilişkin yaklaşamı için bkz: Baron de Montesquieu, The Spirit of the Laws (New York:Hafner, 1962), 66-70 and 120-25.

${ }^{6}$ Modern demokrasiye zemin hazırlayan tarihsel ayaklanmalara ilişkin klasik açıklama için bkz: Robert R.Palmer, The Age of Democratic Revolution: A Political History of Europe and America, 1760-1800, 2 vols., (Princeton, NJ:Princeton University Press, 1959). Modern demokrasinin seçkin bir siyaset bilimi olarak ele alınması ile ilgili olarak bkz: Robert A. Dahl, Democracy and its Critics (New Haven, CT: Yale University Press, 1989). Antik ve modern demokrasi arasındaki ilişkiyi inceleyen ünlü bir çalışma için bkz: Benjamin Constant, "De la libertè des anciens à celle des modernes," in idem Cours de politique constitutionelle ou collection des ouvrages publiès sur le gouvernement représentatif (Paris: Guillaumin, 1872), vol. 2, 539-60.

${ }^{7}$ Minimalist kavramlardan oldukça titiz, karmaşık ve maximalist kavramlara kadar çeşitlilik gösteren farklı tanımlamaları bulunan demokrasi kavramı üzerine siyaset bilimi literatürü. Burada kullanılan bakış açısına benzer bir bakış açısı benimseyen çalışmalara iliş̧in açıklayıcı örnekler için bkz: Dahl, Democracy and its Critics, 108-15 and passim; Juan J. Linz, "Totalitarian and Authoritarian Regimes," in Fred I. Greenstein and Nelson W. Polsby, eds., Handbook of Political Science, vol.3 (Reading, MA: Addison Wesley, 1975), 182-83; and Richard Gunther, P. Nikiforos Diamandouros and Hans-Jürgen Puhle, eds., The Politics of Democratic Consolidation:Southern Europe in Comparative Perspective (Baltimore, MD: Johns Hopkins University Press, 1995), 5-7. "Veto grupları" için bkz: Scott Mainwaring, Guillermo O'Donnell and J. Samuel Valenzuela, eds., Issues in Democratic Consolidation: The New South American Democracies in Comparative Perspective (Notre Dame, IN: University of Notre Dame Press, 1992), 48-49.

${ }^{8}$ Seçim rejimleri ile ilgili olarak bkz:Terry Lynn Karl,"Imposing Consent? Electoralism vs.Democratization in El Salvador," in Paul Drake and Eduardo Silva, eds. Elections and Democratization in Latin America, 1980-85 (San Diego, CA: Centre for Iberian 
and Latin American Studies, 1986), 9-36. Burada gündeme getirilen daha genel sorunlara odaklanan daha yeni bir kavramlaştırma çalışması için bkz: Wolfgang Merkl, "Embedded or Defective Democracies," as well as Merkl and Aurel Croissant, "Conclusion:Good and Defective Democracies," Democratization 11:5 (December 2004), 33-58 and 199-213 respectively.

${ }^{9}$ Demokrasi ve bir devletin meşruiyeti arasındaki ilişki ile ile ilgili olarak bkz: Dahl, Democracy and its Critics, 207, as well as Juan J. Linz and Alfred Stepan, Problems of Democratic Transition and Consolidation:Southern Europe, South America, and Post-Communist Europe (Baltimore, MD: Johns Hopkins University Press, 1996), 26-33 and passim.

${ }^{10}$ Çoğunlukçu demokratik sistemler ve dinamikleri ile ilgili öne sürülen görüşler için bkz: Arend Lijphart, Patterns of Democracy. Government Forms and Performance in Thirty-Six Countries (New Haven, CT:Yale University Press, 1999), 9-30.

${ }^{11}$ Belirli bir ülkeye uygulanan "levelling egalitarianism (eşitliği seviyelendirme)" kavramı için bkz: P. Nikiforos Diamandouros, "Cultural Dualism and Political Change in Postauthoritarian Greece," (Madrid: Juan March Centro de Estudios Avanzados en Ciencias Sociales, 1994, Working Paper 50), 14 and passim.

12 Demokratikleşme üzerinde yapılan son araştırmalar, "kaliteli demokrasi" kavramına giderek daha fazla özen göstermektedir. Konuyu sistematik bir şekilde ele alan son dönemin akademik çalışmalarına ilişkin açıklayıcı örnekler için bkz: Leonardo Morlino, "What is 'Good' Democracy?", Democratization 11:5 (December 2004), 10-32; Guillermo O'Donnell, Jorge Vargas Cullell, and Osvaldo M. lazzetta, eds., The Quality of Democracy: Theory and Applications (Notre Dame, IN: University of Notre Dame Press, 2004). Yukarıda not 3'te belirtilen O'Donnell'in yazdığı makalenin yanı sıra Diamond ve Morlino, Schmitter, Beetham, Rueschemeyer, Powell ve Plattner de 15:4 nolu Demokrasi Dergisi'nde yer alan bu konuya katkılarda bulunmuştur (Ekim 2004) .20-110.

${ }^{13}$ Modern demokratik devletlerin kurumsal mühimmat deposunun bir parçası olan ombudsmanlık kurumu ile ilgili olarak bkz: Andreas Schedler, Larry Diamond and Marc F. Plattner, eds., The Self-Restraining State: Power and Accountability in New Democracies (London: Lynne Rienner, 1999). Geçtiğimiz yıllarda, Danimarka Ombudsmanlık Kurumu, zamanla tipik bir parlamenter Ombudsmanlık Kurumu olarak anılmaya ve taklit edilecek bir örnek gibi uluslararası toplum üzerinde güçlü bir etki bırakmaya başlamıştır. Bu kurumun tarihi ve evrimi üzerine odaklanan, İngilizce hazırlanan yeni çalışma için bkz: Hans Gammeltoft-Hansen and Jens Olsen, eds., The Danish Ombudsman 2005 (Copenhagen: Folkentingets Ombudsmand, 2005). Ayrıca Danimarka'da görevli olan ve Avrupa Ombudsmanlık Kurumları arasında 2005 'ten bu yana hizmet veren dünyanın en uzun süre görev yapan Ombudsmanı olan Hans Gammeltoft-Hansen tarafın konu ile iligli sunduğu genel 
açıklamaya bkz:The European Ombudsman: Origins, Establishment, Evolution (Luxembourg:Office for Official Publications of the European Communities, 2005), 13-26.

14 Eğer, Ombudsmanlık Kurumunun 1809 yılında kurulduğu İsveç, bu alanda sıralamanın en görünür şekilde elde edildiği ve açıklandığı şekilde, klasik bir ülke örneğini teşkil ediyorsa, bu ülke ve Birleşik Krallık dâhil olmak üzere İngiliz Milletler Topluluğu'nda yer alan ülkelerin yanı sıra diğer İskandinav ülkeleri de Ombudsmanlık kurumunun erken kurulması ve sağlam bir şekilde gelişmesi için sağlam bir zemin hazırlamıştır. Bu nedenle, 1970'lerin ortalarında üçüncü demokratikleşme dalgası ortaya çıkıncaya kadar Ombudsmanlık kurumunun başarıyla kurulması ve sadece yedi ülkede ortaya çıkması tesadüfi değildir. Bu yedi ülkeden altısını oluşturan İsveç [1809], Finlandiya [1919], Danimarka [1955], Yeni Zelanda, Norveç [1962] ve Birleşik Krallık [1967] bu geniş kategoride yer almaktadır. Demokratikleşme alanında "üçüncü dalga" kavramı için bkz: Samuel P.Huntington, The Third Wave: Democratization in the Late Twentieth Century (Norman: University of Oklahoma Press, 1991).

${ }^{15}$ Demokratik hesap verebilirlik konusu ile ilgili olarak bkz:Andreas Schedler, "Conceptualizing Accountability," Guillermo O'Donnell “Horizontal Accountability in New Democracies," and Philippe C. Schmitter "The Limits of Horizontal Accountability" in Schedler, Diamond, and Plattner, eds., The Self-Restraining State, 13-28, 29-52, and 59-62. Ayrica bkz: Leonardo Morlino, "What is 'Good' Democracy?" passim.

${ }^{16}$ Ombudsmanlık kuruma ilişkin bu tür bir kavramsallaştırma içerisinde yer alan ve bu kuruma aşırı yüklenilmesine zemin hazırlayan üstü kapalı tehlikelere ilişkin eleştirel bir analiz için bkz: Dimitris Christopoulos and P. Nikiforos Diamandouros, "Traditional Rights Protection Mechanisms and the Rising Role of Mediation in South Eastern Europe," in Christopoulos and Hormovitis, eds., The Ombudsman in South eastern Europe, 30-40.

${ }^{17}$ Avusturya-Macaristan İmparatorluğu'nun halefi olan devletlerle ilgili olarak bu konuya ilişkin daha detaylı bilgi için bkz: P.Nikiforos Diamandouros and F. Stephen Larrrabee, "Democratization in South-Eastern Europe:Theoretical Considerations and Evolving Trends," in Geoffrey Pridham and Tom Gallagher, eds., Experimenting with Democracy:Regime Change in the Balkans (London: Routledge, 2000), 24-64.

${ }^{18}$ Napolyon Savaşlarının sona ermesinden bu yana Güney Avrupa'da hakim olan otoriterlik ve istikrarsız, nihayetinde de başarısız demokratik deneyler arasındaki dalgalanmayı konu edinen tarihsel bir analiz için bkz: Edward E. Malefakis, "The Political and Socioeconomic Contours of Southern European History," in Gunther, Diamandouros, Puhle, eds., The Politics of Democratic Consolidation, 33-76. 
${ }^{19}$ Son yarım yüzyıl veya daha fazla bir süredir Güney Avrupa'da kurulan istikrarlı, konsolide demokratik rejimlerin niteliği ve sonuçları ile ilgili söz konusu sistematik çalışma, American Council of Learned Societies and the Social Science Research Council (New York) 'nin "Güney Avrupa Alt Komitesinin" himayesi altında çıkarılan beş ciltllik serinin ana fikrini oluşturmaktadır. Bu makalede yer verilen sorunlarla ilgili yapılan analizler için daha önce bahsedilen The Politics of Democratic Consolidation çalışmasının yanı sıra bkz: P. Nikiforos Diamandouros and Richard Gunther, eds., Parties, Politics, and Democracy in the New Southern Europe (Baltimore, MD: Johns Hopkins University Press, 2001), and Richard Gunther, P.Nikiforos Diamandouros and Dimitri A. Sotiropoulos, eds., Democracy and the State in the New Southern Europe (forthcoming).

${ }^{20}$ Osmanlı İmparatorluğu'nun varisi olan devletlerde hakim demokrasiye ilişkin bekletiler ile ilgili olarak bkz: Diamandouros and Larrabee, "Democratization in South-Eastern Europe," 24-64.

${ }^{21}$ Demokrasinin çoğunlukçu mantığı göz önünde bulundurularak hukukun üstünlüğü ile ilgili sorunların çözülmesi için atılacak adımlarla beraber ortaya çıkacak sorunların teorik olarak ele alan çalışmalar için yukarıda not 9'da alıntılanan Dahl (1989) and Linz and Stepan (1996)'ın çalışmalarına bakınız. 